\title{
Influence of Artificial Intelligence in Civil Engineering toward Sustainable Development-A Systematic Literature Review
}

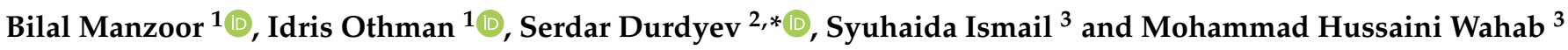 \\ 1 Department of Civil \& Environmental Engineering, University Technology PETRONAS, Seri Iskandar 32610, \\ Perak, Malaysia; bilal_18003504@utp.edu.my (B.M.); idris_othman@utp.edu.my (I.O.) \\ 2 Department of Engineering and Architectural Studies, Ara Institute of Canterbury, \\ Christchurch 8011, New Zealand \\ 3 Razak Faculty of Technology and Informatics, Universiti Teknologi Malaysia, Jalan Sultan Yahya Petra, \\ Kuala Lumpur 54100, Malaysia; syuhaida.kl@utm.my (S.I.); hussaini.kl@utm.my (M.H.W.) \\ * Correspondence: Serdar.Durdyev@ara.ac.nz
}

Citation: Manzoor, B.; Othman, I.; Durdyev, S.; Ismail, S.; Wahab, M.H. Influence of Artificial Intelligence in Civil Engineering toward Sustainable Development-A Systematic Literature Review. Appl. Syst. Innov. 2021, 4, 52. https://doi.org/10.3390/ asi4030052

Academic Editor: Teen-Hang Meen

Received: 29 May 2021

Accepted: 30 July 2021

Published: 6 August 2021

Publisher's Note: MDPI stays neutral with regard to jurisdictional claims in published maps and institutional affiliations.

Copyright: (c) 2021 by the authors. Licensee MDPI, Basel, Switzerland. This article is an open access article distributed under the terms and conditions of the Creative Commons Attribution (CC BY) license (https:// creativecommons.org/licenses/by/ $4.0 /)$

\begin{abstract}
The widespread use of artificial intelligence (AI) in civil engineering has provided civil engineers with various benefits and opportunities, including a rich data collection, sustainable assessment, and productivity. The trend of construction is diverted toward sustainability with the aid of digital technologies. In this regard, this paper presents a systematic literature review (SLR) in order to explore the influence of $\mathrm{AI}$ in civil engineering toward sustainable development. In addition, SLR was carried out by using academic publications from Scopus (i.e., 3478 publications). Furthermore, screening is carried out, and eventually, 105 research publications in the field of AI were selected. Keywords were searched through Boolean operation "Artificial Intelligence" OR "Machine intelligence" OR "Machine Learning" OR "Computational intelligence" OR "Computer vision" OR “Expert systems" OR "Neural networks" AND “Civil Engineering" OR “Construction Engineering" OR "Sustainable Development" OR "Sustainability". According to the findings, it was revealed that the trend of publications received its high intention of researchers in 2020, the most important contribution of publications on AI toward sustainability by the Automation in Construction, the United States has the major influence among all the other countries, the main features of civil engineering toward sustainability are interconnectivity, functionality, unpredictability, and individuality. This research adds to the body of knowledge in civil engineering by visualizing and comprehending trends and patterns, as well as defining major research goals, journals, and countries. In addition, a theoretical framework has been proposed in light of the results for prospective researchers and cholars.
\end{abstract}

Keywords: artificial intelligence; sustainable development; construction; civil engineering; machine learning; construction engineering

\section{Introduction}

Artificial intelligence (AI) is playing a critical role in civil engineering in the direction of digitalization and intelligence, allowing for substantial increases in automation, performance, and reliability, as well as establishing an active connection between physical and digital construction [1,2]. As a large economic sector, construction can influence national growth and development as well as help long-term growth [3]. According to a McKinsey Global Institute survey conducted in 2017, the global construction industry accounts for roughly $13 \%$ of global GDP, with that amount projected to rise to $15 \%$ by 2020 [4]. Furthermore, governments around the world, as well as the world's technology leaders, are putting more effort into the implementation of AI in order to gain a competitive advantage [5]. For example, the U.K. government recently signed an agreement to put the country at the forefront of the AI industry by investing an additional $€ 1.8$ billion to make the country more creative and innovative [6,7]. Similarly, France intends to spend $€ 1.5$ billion on AI science. First, such investments provide advanced economies with a 
competitive advantage at the national level; however, they can have a negative effect on the globalization of production and services $[8,9]$. In the current scenario, industrialized economies outsource resources, such as call centers and manufacturing, to developing economies due to cost advantages [10]. Companies that fully use the capabilities of AI, on the other hand, will no longer have to consider outsourcing costs or living wages [11,12]. Furthermore, rising overhead costs would limit or eliminate the outsourcing of services and output in the developing market, bringing services in-house. This change could result in a reduction in product prices and other company expenditures [13-16].

$\mathrm{AI}$ can be described as a distributed, statistical, and symbolic technique that focuses on simulating human functions before moving on to empathy and is making an effort to mimic acceptable communication and focuses on cognitive tasks before moving into the domain of previous approaches, such as deciding analytical ones, and devotes prior effort to modeling $[17,18]$. In addition, there are three levels of AI, as follows: (a) artificial narrow intelligence (ANI), in which machines only perform one mission, and thus are capable of making decisions on that one aspect of their environment, (b) artificial general intelligence (AGI), the categories of "AGI", which are also known as "powerful AI", "human-level AI", and "real synthetic intelligence" are computers that can find and comprehend the way, think abstractly, plan, figure out problems, learn quickly, and acquire experience quickly. Technologically, economically, or environmentally efficient vehicles and (c) artificial super intelligence (ASI), an intelligence that is far superior to the best human brain in all areas, including scientific ingenuity, general knowledge, and social skills [19-22].

Despite the fact that emerging innovations are opening up new avenues for community participation and governance, cities are still a long way from being genuinely smart and sustainable due to issues of disengagement and exclusivity [23,24]. Despite technological advancements (particularly in computer vision, robotics, and speech recognition), scientists, executives, and government officials have recently expressed concern that AI might endanger the livelihoods and capabilities of businesspeople, automate military operations, and potentially undermine the latter's pride in human superiority $[25,26]$. The world is entering a new period of sustainable growth, in which nations must work together to solve the most intractable issues such as persistent global poverty, social exclusion, economic inequality, poor governance, and environmental degradation $[27,28]$. AI is rapidly opening up a new frontier in the disciplines of sustainable development as a result of the employment of machines and robotics with deep learning capabilities. Deep learning skills have both disrupted and enabled governments and society [17]. They also have an impact on broader global sustainability trends. As AI affects our society, it has the potential to usher in a constructive future in which people cohabit peacefully with robots. More immediately, AI can help us make better progress toward the United Nations (UN) Sustainable Development Goals (SDGs) and push us even further toward sustainability goals [29].

A collection of ideas for understanding and caring for long-term prosperity, in addition to economic growth, with a focus on social security and environmental sustainability [30]. Much research has been conducted on the rise of AI from the beginning of the modern era to the present [31-34]. Throughout the 2000s, with their increasing contributions to AI exploration in the world of concepts, the media and academic journals added AI to a vast body of data, information, and solutions to problems in fields all over the world [35-37]. In addition, AI can use sophisticated algorithms to learn from big data and then apply what it has learned to help the construction industry [38]. Furthermore, AI offers numerous opportunities for substantial efficiency gains by analyzing large amounts of data rapidly and accurately [39]. Furthermore, AI systems and technologies can deal with complex, nonlinear functional problems and, once educated, can make predictions and generalizations at a high rate in digital construction [40,41]. AI has sparked significant interest in a wide variety of areas, including computer science, mechanical engineering, and civil engineering, attracting the attention of researchers [42,43]. 
Some reviews on this subject have been published as a result of the rapid growth of AI applications in civil engineering [44-47]. However, the majority of them only emphasize the importance of $\mathrm{AI}$ in a particular subfield, such as structural engineering [48], building information modeling (BIM) [49], automated construction manufacturing [50], computer vision [51], and others. Furthermore, Darko et al. [52] used scientometric analysis to perform a study on $\mathrm{AI}$ in the architecture, engineering, and construction (AEC) industry in order to increase awareness of $\mathrm{AI}$ in AEC. However, it does not include a thorough introduction to AI techniques and realistic AI applications in civil engineering. Yan et al. [53] conducted a literature review focusing on data mining in the construction industry. Data mining, on the other hand, is a subset of AI that is used to automatically process data and extract valuable insights. A bibliometric analysis of AI engineering applications was recently carried out [54]. However, their research is limited to only one journal's publications and provides a summary of previous work without offering directions for future work.

Therefore, the objectives of this study are:

1. What is the annual publications trend of $\mathrm{AI}$ in civil engineering toward sustainable development from 1995 to 2021 (April)?

2. What are the leading journals' contributions in the direction of $\mathrm{AI}$ in civil engineering toward sustainable development?

3. Investigating the countries where the AI-related studies were performed in the domain of civil engineering and establishing a comparison between developed and developing countries in terms of sustainable development;

4. What are the civil engineering activities, features of civil engineering, and sustainable assessment toward development?

5. What are the future directions recommended on the basis of this study analysis?

In order to overcome this research gap, a systematic literature review (SLR) was used to seek responses to these questions for the benefit of academia and industry. It is anticipated that the answers to these questions would give rise to contributing knowledge in literature.

\section{Research Methodology}

A SLR was carried out through a systemic analysis to achieve the objectives suggested in the introduction of this paper. This approach has been chosen to reduce the risk of errors and make reliability possible [55]. The evaluation was conducted in five stages in accordance with the guidelines of Tranfield et al. [56] and Moher et al. [57], also known as PRISMA statement (i) selection of objectives; (ii) selection of databases; (iii) identification of the keywords; (iv) compatible papers selection; and (v) extraction of data.

Regarding the (i) objective, this study is to explore the influence of AI in civil engineering toward sustainable development as well as civil engineering awareness, civil engineering activities, features of civil engineering, and sustainable assessment. As to (ii) database selection, the authors decided to search within the "Scopus" database. The reason for using the Scopus database is that scientific journal papers are collected more widely than other databases. (iii) keywords were searched through Boolean operation "Artificial Intelligence" OR "Machine intelligence" OR "Machine Learning" OR "Computational intelligence" OR "Computer vision" OR "Expert systems" OR "Neural networks" AND "Civil Engineering" OR "Construction Engineering" OR "Sustainable Development" OR "Sustainability". The first search provided the result of 3478 Scopus papers. (iv) the selection process began, and documents were omitted other than engineering, for example, in connection with medicine, agriculture. Moreover, the papers related to publishing in conferences were also omitted because the conferences papers were not gone through the peer-review process. The number had now been reduced to 320 Scopus documents. Now, another screening process was conducted by evaluating the suitable title and abstract. The final outcome was 105. Afterward, (v) data extraction was subsequently performed. The detailed theme of research methodology is shown in Figure 1. 


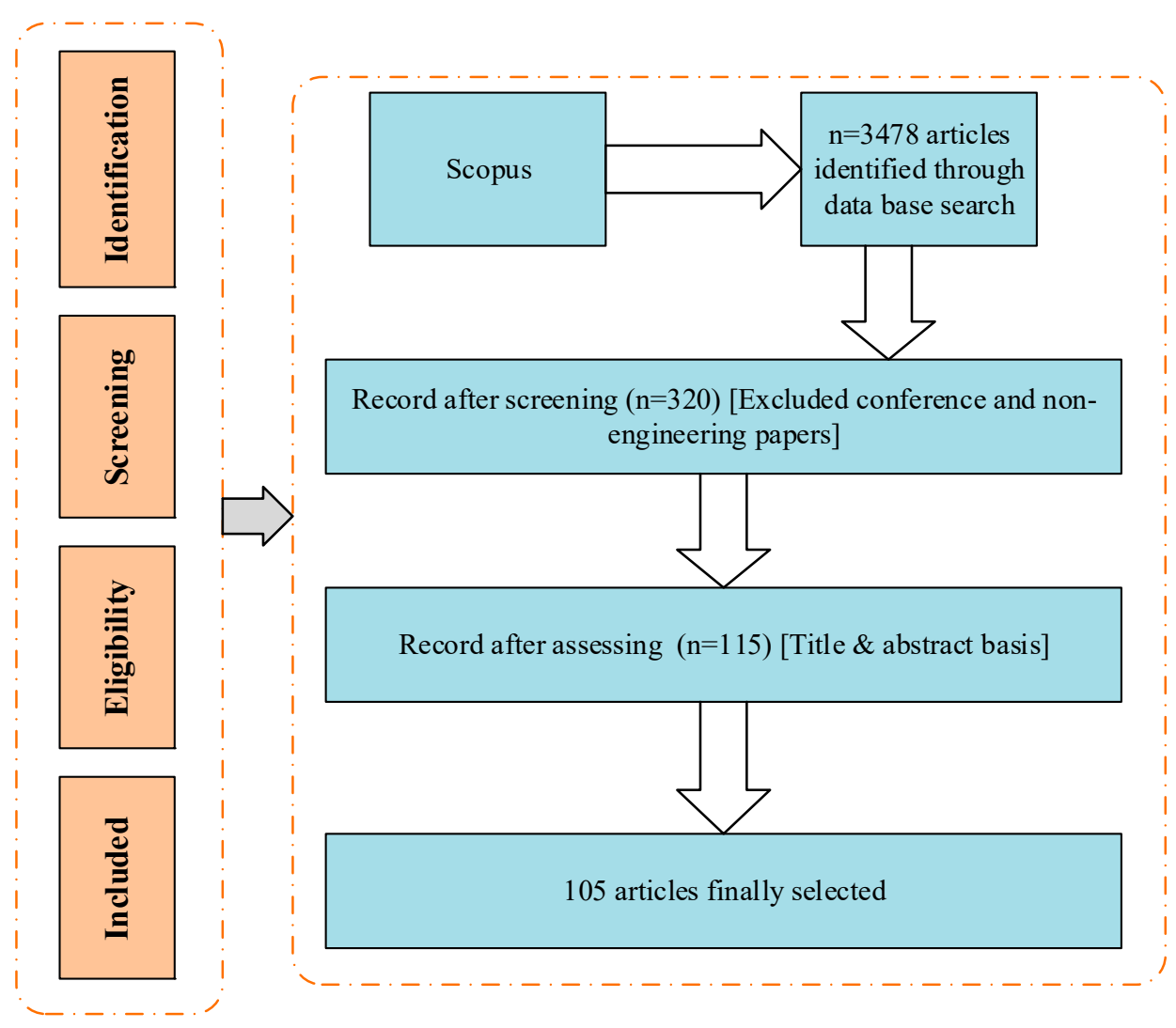

Figure 1. Research flowchart design.

\section{Results and Discussion}

The follow-up section explores in detail the annual publications trend of AI in civil engineering toward sustainable development, contributions of leading journals in terms of $\mathrm{AI}$ in civil engineering toward sustainable development, geospatial distribution, and comparison between developed and developing countries, civil engineering activities toward sustainability, features of civil engineering toward sustainability, AI, and sustainable assessment in order to fulfill the objectives of this study.

\subsection{Annual Publications Trend of AI in Civil Engineering toward Sustainable Development}

The study included 105 publications spanning the years 1995 to 2021(April). It was revealed that the trend of publications received its high intention of researchers in 2020. However, in 2021 (April), the number of publications was 22 in the domain of AI in civil engineering, and this number is expected to increase because the currently included publications were from January-April (2021). The detailed image is depicted in Figure 2. 


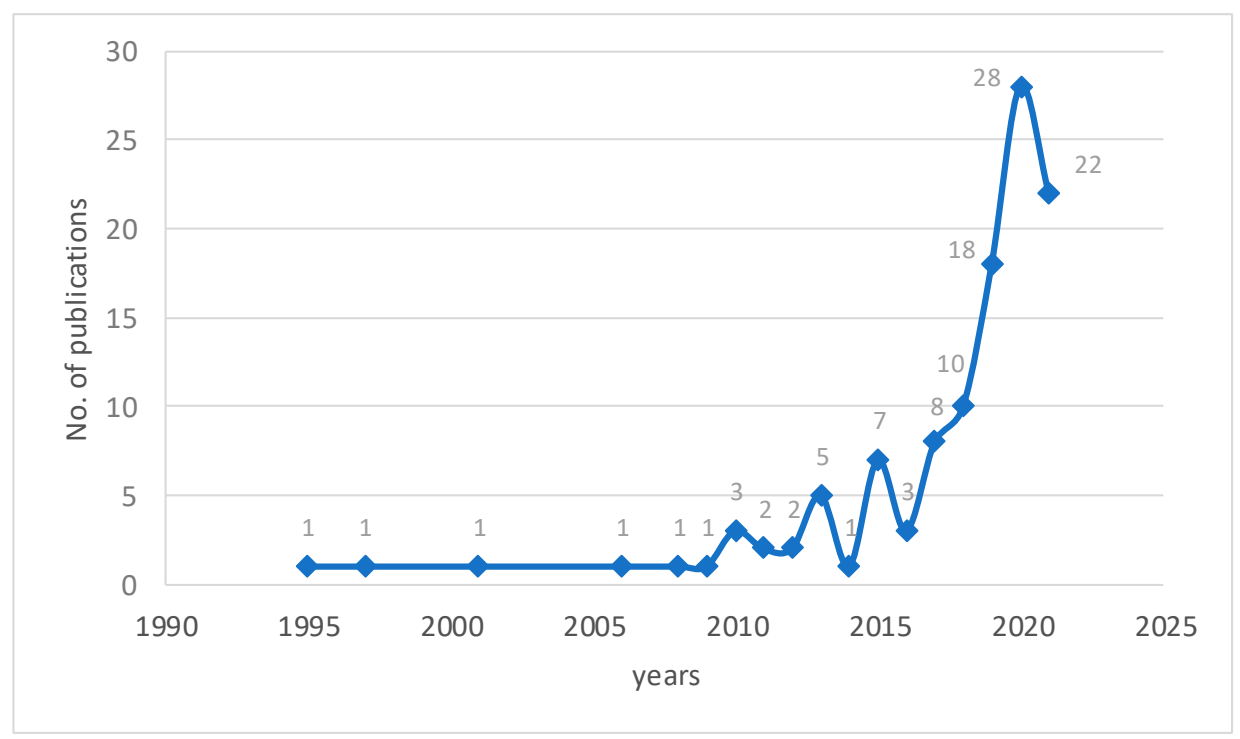

Figure 2. Annual publication trend of AI in civil engineering toward sustainable development.

3.2. Contributions of Leading Journals in Terms of AI in Civil Engineering toward Sustainable Development

Numerous studies emphasize and expound on the significance of conducting research in any field that involves the analysis of academic journals [58-60]. Such information can be useful to scholars in their search for knowledge tools, as well as to readers, who can then assist them in determining which journals are appropriate for publishing works related to AI in civil engineering [61,62]. It was revealed that the contribution of Automation in Construction (61\%) was the greatest achievement, followed by Advances in Civil Engineering (10\%), Buildings (10\%), Journal of Building Engineering (6\%), Energy and Buildings (3\%), and International Journal of Civil Engineering (2\%), with the remaining journals contributing $1 \%$ equally. The detailed picture is shown in Table 1.

Table 1. Contribution of journals toward sustainable development.

\begin{tabular}{ccc}
\hline Research Articles & No. of Articles & Percentage \\
\hline Automation in Construction & 60 & $57 \%$ \\
\hline Advances in Civil Engineering & 11 & $10 \%$ \\
\hline Buildings & 11 & $10 \%$ \\
\hline Journal of Building Engineering & 7 & $7 \%$ \\
\hline Energy and Buildings & 3 & $3 \%$ \\
\hline International Journal of Civil Engineering & $2 \%$ \\
\hline Arabian Journal for Science and Engineering & 2 & $1 \%$ \\
\hline International Journal of Design Sciences and Technology & 1 & $1 \%$ \\
\hline Journal of Architectural Engineering & 1 & $1 \%$ \\
\hline Journal of Engineering Mechanics & 1 & $1 \%$ \\
\hline Journal of Engineering Science and Technology Review & 1 & $1 \%$ \\
\hline Journal of Engineering, Design and Technology & 1 & $1 \%$ \\
\hline Journal of Infrastructure Systems & 1 & $1 \%$ \\
\hline KSCE Journal of Civil Engineering & 1 & $1 \%$ \\
\hline Malaysian Construction Research Journal & 1 & $1 \%$ \\
\hline Open Civil Engineering Journal & 1 & $1 \%$ \\
\hline Structures & 1 & $1 \%$ \\
\hline
\end{tabular}




\subsection{Geospatial Distribution and Comparison between Developed and Developing Countries}

The United States was the most influential in terms of publications, followed by China, the United Kingdom, Singapore, Australia, the United Arab Emirates, Iran, South Korea, Denmark, and Malaysia. However, developed countries (the United States, the United Kingdom, Singapore, Australia, the United Arab Emirates, South Korea, and Denmark) had significantly more impact on publications related to AI in civil engineering than developing countries (China and Malaysia). It is recommended to collaborate with developed countries to share ideas and works that will help to increase the shortage of publications in developing countries. Figure 3 depicts a more detailed picture.

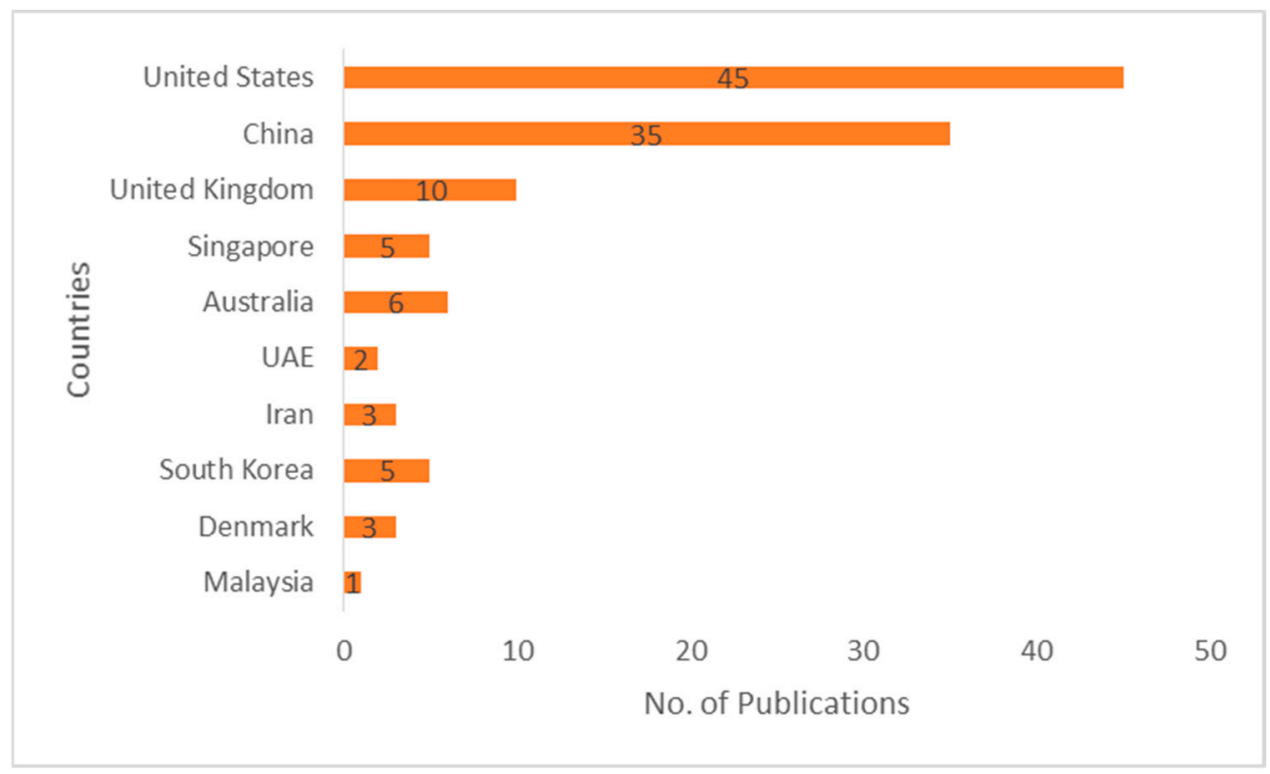

Figure 3. Geospatial distribution of research publications.

\subsection{Civil Engineering Activities toward Sustainability}

Civil engineering activities have an effect on construction during the project's life cycle. These impacts occur during the construction process, operating process, and final demolition as a construct reaches the end of its lifespan.

\subsubsection{During Construction Process}

To ensure a smooth construction phase, comprehensive plans of the project creation related to resources, schedule, cost, and others must be secured prior to the construction process $[63,64]$. There is a need to develop well-documented strategies that include cost reduction, duration, and scheduling of the realistic process. A suitable example is how a graphical representation of the building structures and systems will provide a complete overview during the construction process $[65,66]$. To ensure the effectiveness of these efforts, a comprehensive, flexible technique that serves as a framework for improvement activities is essential. This organized strategy was created as a consequence of the knowledge and experience gained from executing various sorts of improvement operations on numerous construction sites over the last six years. All of these measures have been designed to improve the construction industry's performance by decreasing waste and eliminating non-value-added activities from the building process [67].

\subsubsection{Operating Process}

The project will have entered a new phase when construction is completed, known as operation, and the construction team will begin the operation process when this project is up and running $[68,69]$. The operating method not only helps to operate and maintain a constructed building while also maintaining the safety [70] and comfort of users, but 
it also performs the expected functions during its life cycle [71]. To begin, maintaining a clear service flow of day-to-day operations helps track the facility's hazard and keep it safe while lowering the facility risk by ensuring that the systems work efficiently and that the number of failed operations is kept to a minimum [72,73].

\subsubsection{Demolition Process}

A building may be demolished using various methods or techniques, including (a) blast, (b) wrecking balls, (c) hydraulic crushers and pulverizers, and (d) the top-down process. The method of demolition chosen is determined by the project requirements, site limitations, and equipment availability [74,75]. Demolition sites are typically located in congested areas where space for large machinery such as cranes is often restricted [76]. As a result, the first three demolition methods are typically unsuitable for the majority of demolition projects, and the top-down approach is the most widely used demolition method [77,78].

\subsection{Features of Civil Engineering toward Sustainability}

The key features of civil engineering consist of interconnectivity, functionality, unpredictability, and individuality.

\subsubsection{Interconnectivity}

The interconnectivity of construction projects is most often created from the amount of work and the work combined with the degree of engagement of participation needed for the project $[79,80]$. Furthermore, in the construction industry, multiple workers are allocated, all of the uniform density and interconnected, which means that complex scheduling can be a problem $[81,82]$. The operation process should take a variety of elements into account, such as security, weather, operating hours, and time limit, and in order to deliver successful results smoothly, operations should be designed to take into consideration [83,84]. Furthermore, AI contributes to the automation of critical but time-consuming and repetitive operations, allowing humans to concentrate their time and energy on higher-value work activities. As a result, AI reveals insights that would otherwise be concealed in massive volumes of huge data sets that previously required human management and analysis, such as data generated by videos and images, as well as written reports and business papers, social media posts, and e-mail communications.

\subsubsection{Functionality}

The initial scope and end results of projects are decided upon when they are established. If there are delays, however, the original end-goals become hazy. Changes or circumstances that occur during the lifespan of projects create a variety of needs or for a variety of reasons $[85,86]$. Any shifts in size, such as expansions or decreases, must be accompanied by similar changes in the schedule and budget of the project in order for all aspects of the project's dynamic reality to remain in balance $[87,88]$. The development of automated environmental sustainability studies of products and regions, as well as the optimization of energy use and distribution, is underway. Robotic vehicles that optimize routes and driving styles to reduce carbon emissions are also being developed. While static environmental benefits are determined by the construction, manufacture, and transportation prior to purchase, autonomous environmental objectives are provided from post-purchase autonomous interactions between an $\mathrm{AI}$-enhanced product and its environment, which include knowledge and decision-making, and are determined by the design, production, and distribution of products prior to purchase. A domestic robot, for example, may clean the house and its surroundings autonomously using tools and gadgets that it purchases and collects on its own timetable $[89,90]$. 


\subsubsection{Unpredictability}

In most cases, unknown risks must be detected before they manifest, which means they will invariably jeopardize the overall performance of the project. Notably, complex construction projects have a high degree of unpredictability, which is closely related to a number of variables [91,92]. Furthermore, forecasting and preparation must be carried out prior to construction under considerable uncertainty; specifically, determining the dates, times, and costs are often subject to change [93,94]. Some questions about the architecture design remain unanswered, such as if it can pass audits, if clients are happy with it, and so on. In addition, potential risks may be reduced if uncertainties are recognized and evaluated early on, raising the likelihood of a successful construction project [95-97].

\subsubsection{Individuality}

Construction projects vary from one another due to variations in client specifications, project size, environments, influences, and constraints, which increases the complexity of project management [98]. When applied to a new project, repeating the schedule, design scheme, finance, and strategy is insufficient; therefore, there is no point in taking the first project's budget and plans and attempting to implement them on the new one [99]. Furthermore, designers, architects, contractors, and service providers are essential in any project since a product or service can only be designed with design work and a prototype $[100,101]$. It means that each project is carried out by a distinct group of people, and each group has its own set of characteristics, such as ability, knowledge, experience, and communication skills [102].

\subsection{AI and Sustainable Assessment}

With the current popularity of AI, the widespread availability of sensors, the advent of big data, the growth of e-commerce, the rise of the information culture, the interconnection and convergence of data, knowledge with society, physical space and cyberspace have fundamentally altered the information climate for AI development, ushering in a new evolutionary process [103-106]. New technologies have also permitted the emergence of a new form of AI. These key features include the advent of data-driven perception, Internet-mediated group intelligence, and technology-based human-machine hybrids for reinforcement learning, which both agree on the prediction of what human and media data will support and where each other converge [107-109].

People comprehend with their nervous systems and respond with their bodies. This is useful in explaining AI, which is based on cognitive computation and follows a different design paradigm than that which incorporates human cognition, emotional reasoning, and realistic judgment $[110,111]$. This new age of AI opens the door to a multitude of civil engineering applications in daily life, enabling the construction industry to diversify its goods and products while also using AI to enter uncharted territories for long-term growth [112]. Though impressive, these technologies are highly customized to specific tasks. Each application usually necessitates years of advanced study and thoughtful, one-of-a-kind sustainable construction $[113,114]$.

New information and communication technology can be used to usher in new methods to promote sustainable growth, such as AI and robotics, which includes product design, production, management, testing, and integration of systems in new ways of the entire lifecycle [115-118]. In addition, sensor connectivity, understanding, thinking, perception, control, material, and environmental awareness, as well as human reasoning, must occur during the manufacturing life cycle. Human-machine communication is required, life cycle decisions must be taken, and machine and data analysis and controls must be enforced [119-121]. It is recommended that with application technology, the level and capability of infrastructure construction, single applications, synergy applications, and business growth must be evaluated. The incorporation of AI into sustainable products represents an opportunity to improve these products' environmental sustainability and, as a result, increase consumers' purchasing intentions while also appealing to new con- 
sumer segments who are not attracted to conventional environmental sustainability in the traditional sense. As a result, AI-enabled environmental sustainability can help firms build new competitive advantages and sell their products more effectively to consumers. Simultaneously, the effectiveness of a product varies based on the type of user and the product. When compared to traditional environmental sustainability, AI-based environmental sustainability has the potential to attract more consumers. This may enable firms to employ environmental sustainability to more broadly engage consumers across social boundaries, resulting in increased sales while improving the environment.

In the field of civil engineering, the value of AI is extremely great. However, the value of AI toward water resource management and sustainability is discussed here.

\subsubsection{Value of AI toward Water Resource Management}

Water is essential for human survival. Thousands of years of human settlement and improvement decisions have been inextricably related to a reliable supply of safe and nutritious water [122,123]. One-third of the world's water is used in irrigation, with the remainder used for drinking and domestic purposes. Cities and societies all over the world work on a staggering amount of freshwater, processed water, and wastewater every day to meet the needs of human society $[124,125]$. Water must be treated and transported in accordance with hygiene and health standards to ensure that its material and properties meet the specifications of end-users [126,127]. Since artificial intelligence now enables managers to perform two things for water utility management: first, combine long-term growth projections with existing facilities and systems to anticipate future supply, and second, invest in new infrastructure based on results [128]. In general, the results of AI are only as useful as the data fed into it, and the performance generated by it is only as fully interpreted as the intentions of the organization that has it. As with all AI, as AI asks the questions and offers the answers, humans lose some of the information gained from solving the problems themselves [129-131]. The overall issue may be more visible, but it is not required for any particular answer to be given now. Solutions to other problems already perform several times better than human interaction, where things have a plurality of solutions, the tipping point moves from human interaction to automated responses.

\subsubsection{Value of AI toward Sustainability}

As discussions, conversations, awareness, and campaigns have expanded over the years, and new and emerging technologies, such as AI, have entered the civil engineering market, the emphasis has shifted away from the environment and toward AI [132,133]. Though pushing the limits of human creativity, several organizations, including Microsoft, Google, and Tesla, have made significant efforts to create "earth-friendly" AI systems [134]. Other cases have shown that it is possible, such as Google's own DeepMind AI assisting the organization in reducing data center energy usage by $40 \%$ while also lowering overall (greenhouse gas emission) GHG emissions. Advancing AI architecture has added 3\% to global energy demand through data centers and has also led to ensuring sustainable energy access for people living in rural and off-grid areas while also being active in micro grids and exploring ways to integrate renewable resources [135-137]. Furthermore, in cities, AI can be used to track and control the use of electrical power distribution, with artificial grids being used to generate less electricity, making them less unreliable [138]. It is the responsibility of researchers and scientists to ensure that the data collected from AI systems are completely transparent, unbiased, reliable, and credible [139]. Greater demand for automation, as well as more stringent environmental requirements and phenomena, is accompanied by rising demand for technologies with higher levels of analysis and study-driven precision, which necessitates increased investment in $R \& D$, development, both in multinationals and in education and government, in the latter sectors. 


\section{Summary of Findings}

A brief summary of results is discussed in the domain of civil engineering sub-fields. It can be seen that AI has had a major effect and made impressive advances in all sub-fields of civil engineering. The details are shown in Table 2.

Table 2. Summary of findings of AI in civil engineering.

\begin{tabular}{|c|c|c|c|c|c|c|}
\hline Sr No. & Applications of AI & $\begin{array}{l}\text { Structure } \\
\text { Engineering }\end{array}$ & $\begin{array}{c}\text { Construction } \\
\text { Engineering and } \\
\text { Management }\end{array}$ & $\begin{array}{c}\text { Transportation } \\
\text { Engineering }\end{array}$ & $\begin{array}{l}\text { Hydraulic } \\
\text { Engineering }\end{array}$ & $\begin{array}{l}\text { Geotechnical } \\
\text { Engineering }\end{array}$ \\
\hline 1 & $\begin{array}{l}\text { Developing model of steel structure using } \mathrm{AI} \text { and } \\
\text { machine learning tools }\end{array}$ & $\checkmark$ & & & & \\
\hline 2 & $\begin{array}{l}\text { Nano-material with an artificial carbonate can be used in } \\
\text { nano-crystalline crystals }\end{array}$ & $\checkmark$ & & & & \\
\hline 3 & Artificial neural network & & & & & $\checkmark$ \\
\hline 4 & $\begin{array}{c}\text { To ensure irrigation and application of pesticides and } \\
\text { herbicides are applied more effectively }\end{array}$ & & & & $\checkmark$ & \\
\hline 5 & Slope stability & & & & & $\checkmark$ \\
\hline 6 & Optimization of water demand forecasting & & & & $\checkmark$ & \\
\hline 7 & AI focused on edge computing irrigation systems & & & & $\checkmark$ & \\
\hline 8 & Deep neural assessment of friction angle clay & & & & & $\checkmark$ \\
\hline 9 & Forecasting daily lake level & & & & $\checkmark$ & \\
\hline 10 & Bio-inspired computational intelligence & & & $\checkmark$ & & \\
\hline 11 & Innovation management and machine learning approach & & $\checkmark$ & & & \\
\hline 12 & Forecasting to monthly discharge time series & & & & $\checkmark$ & \\
\hline 13 & Pile foundation machine learning approach & & & & & $\checkmark$ \\
\hline 14 & $\mathrm{AI}$ approaches for management risk assessment & & $\checkmark$ & & & \\
\hline 15 & $\begin{array}{l}\text { Multivariate transportation problem and its } \\
\text { implementation }\end{array}$ & & & $\checkmark$ & & \\
\hline 16 & Vehicle traffic load prediction & & & $\checkmark$ & & \\
\hline 17 & Analysis and design of sustainable structures & $\checkmark$ & & & & \\
\hline 18 & Neural network approaches for cost estimation & & $\checkmark$ & & & \\
\hline 19 & Multi-agent system for traffic & & & $\checkmark$ & & \\
\hline 20 & Structural health monitoring & $\checkmark$ & & & & \\
\hline 21 & Investigating the soil properties & & & & & $\checkmark$ \\
\hline
\end{tabular}

\section{Theoretical Framework and Future Directions}

The overview of results serves as the foundation for the conceptual framework. It has been discovered that $\mathrm{AI}$ has a tremendous effect on construction activities such as computer vision, robotic construction, electronic augmentation, machine learning, digitalization, collaboration, and synchronization. While civil engineering includes several sub-fields such as structural engineering, construction engineering and management, transportation engineering, hydraulic engineering, geotechnical engineering, and environmental engineering, the role of $\mathrm{AI}$ in digitalization cannot be overstated. Machine learning techniques, in coordination with remote cameras and unmanned aerial vehicles (UAVs), provide promising non-contact solutions to civil infrastructure condition assessment in structural engineering.

Furthermore, in the transportation field, computer vision-based condition management techniques are used on railway networks. These approaches may be used to obtain data from computers for the purpose of tracking rail conditions [140]. The use of AI in the modeling of semi-arid area infiltration is important in hydraulic engineering. Infiltration is vital to stream flow, groundwater recharge, subsurface flow, and the quality and quantity of surface and subsurface water. In addition, landslides and slope failures are serious issues because they can result in the loss of life and property [141]. As a result, slope stability analysis is one of the most critical geotechnical engineering issues. Slope failures, like most geotechnical problems, are complex. The slope stability research had evolved in tandem with advances in computational geotechnical engineering [142,143]. Furthermore, rein- 
forcement learning is a broad class of optimum control systems that increase performance in a highly dynamic, stochastic environment by estimating value functions obtained from experience, modeling, or search. The interactive environment promotes reinforcement learning, resulting in greater learning ability and adaptability. Because reinforcement learning does not need the use of a system dynamics model, it is a potential choice for ensuring long-term sustainability. The use of reinforcement learning in sustainability is certain to change the old way of energy use, and the system will gain intelligence.

Similarly, the rise of AI is expected to have an effect on global competitiveness, environmental assessment techniques, and long-term sustainability [144]. AI will produce data for more intelligent intervention targeting, minimize waste and losses in production and use, build new technologies that will change whole industries and careers, provide the requisite improvements in communication and cost savings, and bring the benefits of the rapid pace of technological growth to many people around the world. Furthermore, this theoretical framework laid a foundation for future researchers, policymakers, and practitioners to explore the limitations in future research. Figure 4 shows the findings and future directions in the theoretical framework. Furthermore, a recent study conducted by AlArjani et al. [145] built the framework for Saudi Arabia's sustainable development goals. It has made significant contributions to the body of knowledge by concentrating and spending greater resources on alternative energy sources such as solar, wind, biomass, and nuclear energy. In comparison to the current study, greater attention is placed on $\mathrm{AI}$ in civil engineering by emphasizing publishing trends, journal contributions, and aspects of civil engineering toward sustainability.
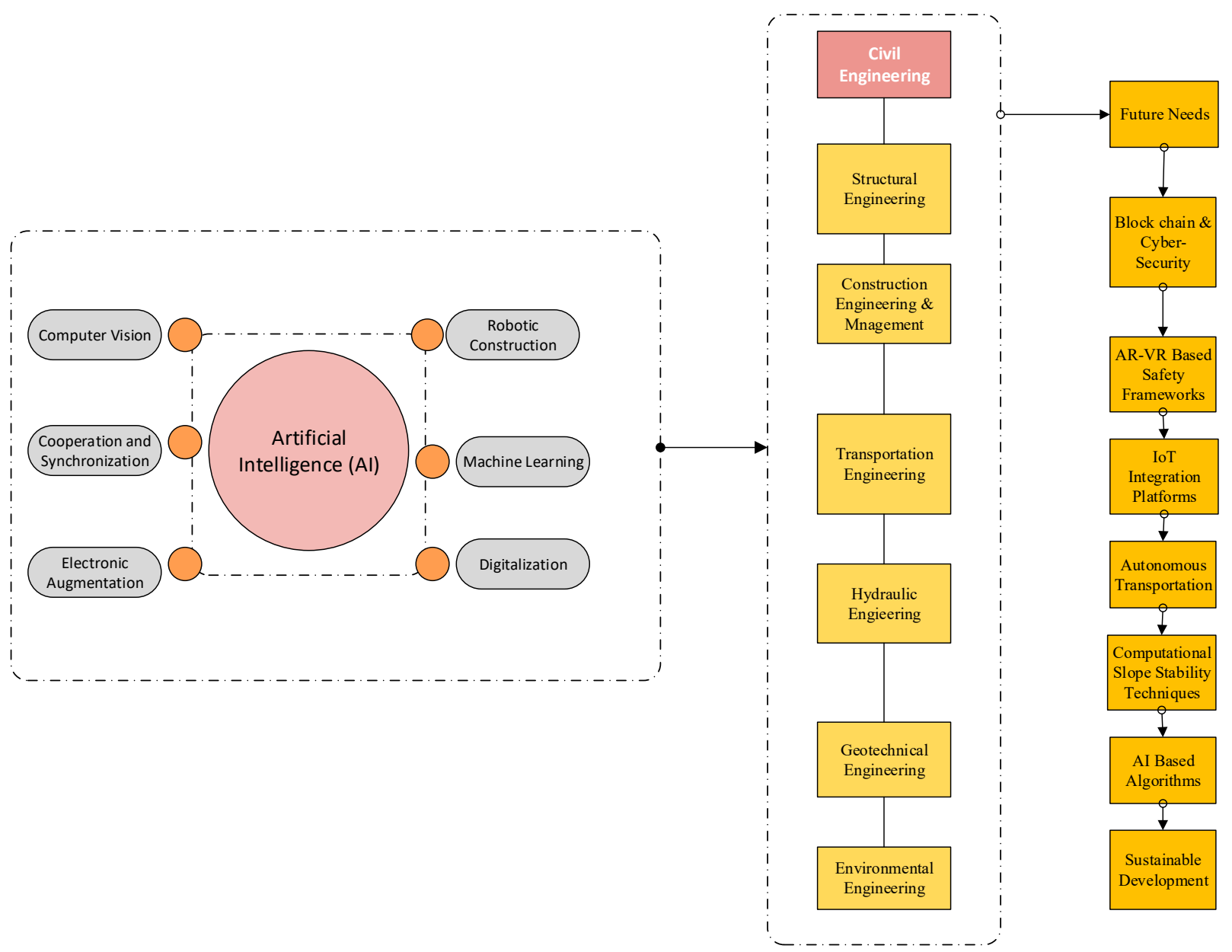

Figure 4. Theoretical framework. 


\section{Conclusions and Limitations}

It was found that the pattern of publications in the domain of $\mathrm{AI}$ in civil engineering was received high attention in 2020. Furthermore, Automation in construction had played a significant role in AI-related publication works. However, it was discovered that developed countries paid more attention to AI research than developing countries. The contributions of this review are (i) to have a fundamental understanding of civil engineering and to demonstrate the possible importance of $\mathrm{AI}$ in supporting and enhancing construction work (ii) to discuss the influence of AI and sustainable assessment, which provides substantial evidence highlighting the benefits of AI techniques (iii) to provide a theoretical framework that will aid potential researchers in incorporating findings. It was revealed that AI had demonstrated the potential to accelerate the learning process, as well as to simplify and augment reasoning, which is useful in construction projects that differ in their basic characteristics. Technology and creativity have resulted in tremendous improvements in our living conditions. Technology development and innovation will also be at the forefront of the transition to a more sustainable future. Productivity-enhancing digital technologies such as AI can help to increase productivity, reduce production costs and emissions, reduce the intensity of production process resources, improve market correspondence, and enable the use of big data to make public services more accessible. From a theoretical approach, the recommendations presented in this research provide guidance on how to address any shortcomings in the process of defining additional research. From a practical aspect, this research can provide practitioners a modulated reference point that is easily accessible, as well as assist them in grasping the most recent techniques and methodology of artificial intelligence research aimed at sustainable development. This research has limitations, despite its contributions. The information is initially obtained from the Scopus database. In the future, additional data will be gathered by combining information from various databases for quantitative and qualitative studies (e.g., Google Scholar, Web of Science, and so on). Second, the focus of this study was limited to journal articles. As a matter of fact, the study's findings do not completely reflect the available AI literature. The limitations mentioned above offer excellent opportunities for further study, but they should be considered when assessing the research results.

Author Contributions: B.M.: Conceptualization, Investigation, Data creation, Writing-original draft; I.O.: Supervision, Writing—review and editing; S.D.: Writing—review and editing; S.I.: Writing-original draft; M.H.W.: Writing—review and editing. All authors have read and agreed to the published version of the manuscript.

Funding: This research received no external funding.

Institutional Review Board Statement: Not applicable.

Informed Consent Statement: Not applicable.

Conflicts of Interest: The authors declare no conflict of interest.

\section{References}

1. Tavana Amlashi, A.; Alidoust, P.; Pazhouhi, M.; Pourrostami Niavol, K.; Khabiri, S.; Ghanizadeh, A.R. AI-based formulation for mechanical and workability properties of eco-friendly concrete made by waste foundry sand. J. Mater. Civ. Eng. 2021, 33, 4021038. [CrossRef]

2. Luckey, D.; Fritz, H.; Legatiuk, D.; Dragos, K.; Smarsly, K. Artificial intelligence techniques for smart city applications. In Proceedings of the International Conference on Computing in Civil and Building Engineering, Sao Paulo, Brazil, 18-20 August 2020; Springer: New York, NY, USA, 2020; pp. 3-15.

3. Giang, D.T.H.; Pheng, L.S. Role of construction in economic development: Review of key concepts in the past 40 years. Habitat Int. 2011, 35, 118-125. [CrossRef]

4. Barbosa, F.; Woetzel, J.; Mischke, J. Reinventing Construction: A Route of Higher Productivity; McKinsey Global Institute: Chicago, IL, USA, 2017.

5. Donepudi, P.K.; Ahmed, A.A.A.; Saha, S. Emerging Market Economy (EME) and Artificial Intelligence (AI): Consequences for the Future of Jobs. PalArch's J. Archaeol. Egypt/Egyptol. 2020, 17, 5562-5574. 
6. Stojčić, M.; Zavadskas, E.K.; Pamučar, D.; Stević, Ž.; Mardani, A. Application of MCDM methods in sustainability engineering: A literature review 2008-2018. Symmetry 2019, 11, 350. [CrossRef]

7. Shirowzhan, S.; Tan, W.; Sepasgozar, S.M.E. Digital twin and CyberGIS for improving connectivity and measuring the impact of infrastructure construction planning in smart cities. Int. J. Geo-Inf. 2020, 9, 240. [CrossRef]

8. Taeihagh, A. Governance of artificial intelligence. Policy Soc. 2021, 40, 137-157. [CrossRef]

9. Pamučar, D.; Božanić, D.; Lukovac, V.; Komazec, N. Normalized weighted geometric bonferroni mean operator of interval rough numbers-application in interval rough dematel-copras model. Facta Univ. Ser. Mech. Eng. 2018, 16, 171-191.

10. Mardani, A.; Streimikiene, D.; Zavadskas, E.K.; Cavallaro, F.; Nilashi, M.; Jusoh, A.; Zare, H. Application of Structural Equation Modeling (SEM) to solve environmental sustainability problems: A comprehensive review and meta-analysis. Sustainability 2017, 9, 1814. [CrossRef]

11. Mardani, A.; Zavadskas, E.K.; Govindan, K.; Amat Senin, A.; Jusoh, A. VIKOR technique: A systematic review of the state of the art literature on methodologies and applications. Sustainability 2016, 8, 37. [CrossRef]

12. De la Fuente, A.; Blanco, A.; Armengou, J.B.; Aguado, A. Sustainability based-approach to determine the concrete type and reinforcement configuration of TBM tunnels linings. Case study: Extension line to Barcelona Airport T1. Tunn. Undergr. Sp. Technol. 2017, 61, 179-188. [CrossRef]

13. Mardani, A.; Zavadskas, E.K.; Streimikiene, D.; Jusoh, A.; Khoshnoudi, M. A comprehensive review of data envelopment analysis (DEA) approach in energy efficiency. Renew. Sustain. Energy Rev. 2017, 70, 1298-1322. [CrossRef]

14. Adeli, H. Four decades of computing in civil engineering. In Proceedings of the CIGOS 2019: Innovation for Sustainable Infrastructure, Hanoi, Vietnam, 31 October-1 November 2019; Springer: New York, NY, USA, 2020; pp. 3-11.

15. Yucel, M.; Nigdeli, S.M.; Bekdaş, G. Artificial neural networks (anns) and solution of civil engineering problems: Anns and prediction applications. In Artificial Intelligence and Machine Learning Applications in Civil, Mechanical, and Industrial Engineering; IGI Global: Hershey, PA, USA, 2020; pp. 13-38.

16. Durdyev, S. Review of construction journals on causes of project cost overruns. Eng. Constr. Archit. Manag. 2020, 28. [CrossRef]

17. Goralski, M.A.; Tan, T.K. Artificial intelligence and sustainable development. Int. J. Manag. Educ. 2020, 18, 100330. [CrossRef]

18. Feroz, A.K.; Zo, H.; Chiravuri, A. Digital transformation and environmental sustainability: A review and research agenda. Sustainability 2021, 13, 1530. [CrossRef]

19. Verhoef, P.C.; Broekhuizen, T.; Bart, Y.; Bhattacharya, A.; Dong, J.Q.; Fabian, N.; Haenlein, M. Digital transformation: A multidisciplinary reflection and research agenda. J. Bus. Res. 2021, 122, 889-901. [CrossRef]

20. Kamble, S.S.; Gunasekaran, A.; Gawankar, S.A. Sustainable Industry 4.0 framework: A systematic literature review identifying the current trends and future perspectives. Process. Saf. Environ. Prot. 2018, 117, 408-425. [CrossRef]

21. Kunkel, S.; Matthess, M. Digital transformation and environmental sustainability in industry: Putting expectations in Asian and African policies into perspective. Environ. Sci. Policy 2020, 112, 318-329. [CrossRef]

22. Qureshi, A.H.; Alaloul, W.S.; Manzoor, B.; Musarat, M.A.; Saad, S.; Ammad, S. Implications of Machine Learning Integrated Technologies for Construction Progress Detection Under Industry 4.0 (IR 4.0). In Proceedings of the 2020 Second International Sustainability and Resilience Conference: Technology and Innovation in Building Designs (51154), Sakheer, Bahrain, 11-12 November 2020; IEEE: Piscataway, NJ, USA, 2020; pp. 1-6.

23. Pongiglione, M.; Calderini, C. Sustainable structural design: Comprehensive literature review. J. Struct. Eng. 2016, 142, 4016139. [CrossRef]

24. Pan, Y.; Zhang, L. Roles of artificial intelligence in construction engineering and management: A critical review and future trends. Autom. Constr. 2021, 122, 103517. [CrossRef]

25. Wang, Y.; Szeto, W.Y. Multiobjective environmentally sustainable road network design using Pareto optimization. Comput. Civ. Infrastruct. Eng. 2017, 32, 964-987. [CrossRef]

26. Ibem, E.O.; Laryea, S. Survey of digital technologies in procurement of construction projects. Autom. Constr. 2014, 46, 11-21. [CrossRef]

27. Zavadskas, E.K.; Antuchevičienè, J.; Kapliński, O. Multi-criteria decision making in civil engineering: Part I-a state-of-the-art survey. Eng. Struct. Technol. 2015, 7, 103-113. [CrossRef]

28. Yi, W.; Wang, S. Multi-objective mathematical programming approach to construction laborer assignment with equity consideration. Comput. Civ. Infrastruct. Eng. 2016, 31, 954-965. [CrossRef]

29. Di Vaio, A.; Palladino, R.; Hassan, R.; Escobar, O. Artificial intelligence and business models in the sustainable development goals perspective: A systematic literature review. J. Bus. Res. 2020, 121, 283-314. [CrossRef]

30. Mitropoulos, L.K.; Prevedouros, P.D. Incorporating sustainability assessment in transportation planning: An urban transportation vehicle-based approach. Transp. Plan. Technol. 2016, 39, 439-463. [CrossRef]

31. Zhang, L.; Pan, Y.; Wu, X.; Skibniewski, M.J. Introduction to Artificial Intelligence. In Artificial Intelligence in Construction Engineering and Management; Springer: New York, NY, USA, 2021; pp. 1-15.

32. Vyas, M.; Thakur, S.; Riyaz, B.; Bansal, K.K.; Tomar, B.; Mishra, V. Artificial intelligence: The beginning of a new era in pharmacy profession. Asian J. Pharm 2018, 12, 72-76.

33. Brynjolfsson, E.; Rock, D.; Syverson, C. Artificial intelligence and the modern productivity paradox: A clash of expectations and statistics. In The Economics of Artificial Intelligence: An Agenda; University of Chicago Press: Chicago, IL, USA, 2018 ; pp. $23-57$. 
34. Zawacki-Richter, O.; Marín, V.I.; Bond, M.; Gouverneur, F. Systematic review of research on artificial intelligence applications in higher education-where are the educators? Int. J. Educ. Technol. High. Educ. 2019, 16, 1-27. [CrossRef]

35. Nishant, R.; Kennedy, M.; Corbett, J. Artificial intelligence for sustainability: Challenges, opportunities, and a research agenda. Int. J. Inf. Manag. 2020, 53, 102104. [CrossRef]

36. Abduljabbar, R.; Dia, H.; Liyanage, S.; Bagloee, S.A. Applications of artificial intelligence in transport: An overview. Sustainability 2019, 11, 189. [CrossRef]

37. Lv, Z.; Chen, D.; Lou, R.; Alazab, A. Artificial intelligence for securing industrial-based cyber-physical systems. Futur. Gener. Comput. Syst. 2021, 117, 291-298. [CrossRef]

38. Alrukaibi, F.; Alsaleh, R.; Sayed, T. Applying Machine Learning and Statistical Approaches for Travel Time Estimation in Partial Network Coverage. Sustainability 2019, 11, 3822. [CrossRef]

39. Patrício, D.I.; Rieder, R. Computer vision and artificial intelligence in precision agriculture for grain crops: A systematic review. Comput. Electron. Agric. 2018, 153, 69-81. [CrossRef]

40. Qin, W.; Lin, Q. Construction of cultural industry development factor model based on factor analysis, artificial intelligence and big data. Microprocess. Microsyst. 2021, 82, 103880.

41. Manzoor, B.; Othman, I. Safety Management Model During Construction Focusing on Building Information Modeling (BIM). In Proceedings of the Advances in Civil Engineering Materials: Selected Articles from the International Conference on Architecture and Civil Engineering (ICACE2020), Chattogram, Bangladesh, 21-23 December 2020; Springer Nature: Basingstoke, UK, 2021; p. 31.

42. Zhu, X. Research on the reform of higher automotive engineering education under the background of artificial intelligence. E3S Web Conf. 2021, 245, 3091. [CrossRef]

43. Araszkiewicz, K. Digital Technologies in Facility Management-the state of practice and research challenges. Procedia Eng. 2017, 196, 1034-1042. [CrossRef]

44. Toorajipour, R.; Sohrabpour, V.; Nazarpour, A.; Oghazi, P.; Fischl, M. Artificial intelligence in supply chain management: A systematic literature review. J. Bus. Res. 2021, 122, 502-517. [CrossRef]

45. Núñez-Merino, M.; Maqueira-Marín, J.M.; Moyano-Fuentes, J.; Martínez-Jurado, P.J. Information and digital technologies of Industry 4.0 and Lean supply chain management: A systematic literature review. Int. J. Prod. Res. 2020, 58, 5034-5061. [CrossRef]

46. Mihic, M.; Vukomanovic, M.; Završki, I. Review of previous applications of innovative information technologies in construction health and safety. Organ. Technol. Manag. Constr. Int. J. 2019, 11, 1952-1967.

47. Bosch-Sijtsema, P.; Claeson-Jonsson, C.; Johansson, M.; Roupe, M. The hype factor of digital technologies in AEC. Constr. Innov. 2021. ahead of print. [CrossRef]

48. Salehi, H.; Burgueño, R. Emerging artificial intelligence methods in structural engineering. Eng. Struct. 2018, 171, 170-189. [CrossRef]

49. Zou, Y.; Kiviniemi, A.; Jones, S.W. A review of risk management through BIM and BIM-related technologies. Saf. Sci. 2017, 97, 88-98. [CrossRef]

50. Hatami, M.; Flood, I.; Franz, B.; Zhang, X. State-of-the-Art Review on the Applicability of AI Methods to Automated Construction Manufacturing. Computing in Civil Engineering 2019: Data, Sensing, and Analytics, Atlanta, Georgia, 17-19 June 2019; American Society of Civil Engineers: Reston, VA, USA, 2019; pp. 368-375.

51. Kakani, V.; Nguyen, V.H.; Kumar, B.P.; Kim, H.; Pasupuleti, V.R. A critical review on computer vision and artificial intelligence in food industry. J. Agric. Food Res. 2020, 2, 100033. [CrossRef]

52. Darko, A.; Chan, A.P.C.; Adabre, M.A.; Edwards, D.J.; Hosseini, M.R.; Ameyaw, E.E. Artificial intelligence in the AEC industry: Scientometric analysis and visualization of research activities. Autom. Constr. 2020, 112, 103081. [CrossRef]

53. Yan, H.; Yang, N.; Peng, Y.; Ren, Y. Data mining in the construction industry: Present status, opportunities, and future trends. Autom. Constr. 2020, 119, 103331. [CrossRef]

54. Shukla, A.K.; Janmaijaya, M.; Abraham, A.; Muhuri, P.K. Engineering applications of artificial intelligence: A bibliometric analysis of 30 years (1988-2018). Eng. Appl. Artif. Intell. 2019, 85, 517-532. [CrossRef]

55. Mulrow, C.D. Systematic reviews: Rationale for systematic reviews. BMJ 1994, 309, 597-599. [CrossRef]

56. Tranfield, D.; Denyer, D.; Smart, P. Towards a methodology for developing evidence-informed management knowledge by means of systematic review. Br. J. Manag. 2003, 14, 207-222. [CrossRef]

57. Moher, D.; Liberati, A.; Tetzlaff, J.; Altman, D.G.; Group, P. Preferred reporting items for systematic reviews and meta-analyses: The PRISMA statement. PLoS Med. 2009, 6, e1000097. [CrossRef] [PubMed]

58. Serenko, A. The development of an AI journal ranking based on the revealed preference approach. J. Inform. 2010, 4, 447-459. [CrossRef]

59. Bobrow, D. Artificial Intelligence in perspective, a retrospective on fifty volumes of the Artificial Intelligence Journal. Artif. Intell. 1994, 59, 5-20. [CrossRef]

60. Azhar, S. Building information modeling (BIM): Trends, benefits, risks, and challenges for the AEC industry. Leadersh. Manag. Eng. 2011, 11, 241-252. [CrossRef]

61. Hosseini, M.R.; Maghrebi, M.; Akbarnezhad, A.; Martek, I.; Arashpour, M. Analysis of citation networks in building information modeling research. J. Constr. Eng. Manag. 2018, 144, 4018064. [CrossRef] 
62. Badrinath, A.C.; Chang, Y.; Hsieh, S. A review of tertiary BIM education for advanced engineering communication with visualization. Vis. Eng. 2016, 4, 1-17. [CrossRef]

63. Al-Reshaid, K.; Kartam, N.; Tewari, N.; Al-Bader, H. A project control process in pre-construction phases: Focus on effective methodology. Eng. Constr. Archit. Manag. 2005, 12, 351-372. [CrossRef]

64. Osipova, E. Risk management in the different phases of a construction project: A study of actors' involvement. In Proceedings of the Nordic Conference on Construction Economics and Organsiation, Luleå, Sweden, 14-15 June 2007; Luleå Tekniska Universitet: Luleå, Sweden, 2007; pp. 307-319.

65. Noktehdan, M.; Shahbazpour, M.; Zare, M.R.; Wilkinson, S. Innovation management and construction phases in infrastructure projects. J. Constr. Eng. Manag. 2019, 145, 4018135. [CrossRef]

66. Durdyev, S.; Hosseini, M.R. Causes of delays on construction projects: A comprehensive list. Int. J. Manag. Proj. Bus. 2019, 13, 20-46. [CrossRef]

67. Yaseen, Z.M.; Ali, Z.H.; Salih, S.Q.; Al-Ansari, N. Prediction of risk delay in construction projects using a hybrid artificial intelligence model. Sustainability 2020, 12, 1514. [CrossRef]

68. Yang, J.-B.; Wei, P.-R. Causes of delay in the planning and design phases for construction projects. J. Archit. Eng. 2010, 16, 80-83. [CrossRef]

69. Chan, D.W.M.; Kumaraswamy, M.M. A comparative study of causes of time overruns in Hong Kong construction projects. Int. J. Proj. Manag. 1997, 15, 55-63. [CrossRef]

70. Manzoor, B.; Othman, I.; Manzoor, M. Evaluating the critical safety factors causing accidents in high-rise building projects. Ain Shams Eng. J. 2021. [CrossRef]

71. Odeh, A.M.; Battaineh, H.T. Causes of construction delay: Traditional contracts. Int. J. Proj. Manag. 2002, 20, 67-73. [CrossRef]

72. Kabirifar, K.; Mojtahedi, M. The impact of Engineering, Procurement and Construction (EPC) phases on project performance: A case of large-scale residential construction project. Buildings 2019, 9, 15. [CrossRef]

73. Demirkesen, S.; Ozorhon, B. Impact of integration management on construction project management performance. Int. J. Proj. Manag. 2017, 35, 1639-1654. [CrossRef]

74. Luciano, A.; Cutaia, L.; Cioffi, F.; Sinibaldi, C. Demolition and construction recycling unified management: The DECORUM platform for improvement of resource efficiency in the construction sector. Environ. Sci. Pollut. Res. 2020, 28, 24558-24569. [CrossRef] [PubMed]

75. Pantini, S.; Rigamonti, L. Is selective demolition always a sustainable choice? Waste Manag. 2020, 103, 169-176. [CrossRef]

76. Marzouk, M.; Elmaraghy, A.; Voordijk, H. Lean Deconstruction Approach for Buildings Demolition Processes using BIM. Lean Constr. J. 2019, 9, 147-173.

77. Alba-Rodríguez, M.D.; Martínez-Rocamora, A.; González-Vallejo, P.; Ferreira-Sánchez, A.; Marrero, M. Building rehabilitation versus demolition and new construction: Economic and environmental assessment. Environ. Impact Assess. Rev. 2017, 66, 115-126. [CrossRef]

78. Bastianoni, S.; Galli, A.; Pulselli, R.M.; Niccolucci, V. Environmental and economic evaluation of natural capital appropriation through building construction: Practical case study in the Italian context. AMBIO A J. Hum. Environ. 2007, 36, 559-565. [CrossRef]

79. Lebcir, R.M.; Choudrie, J. A dynamic model of the effects of project complexity on time to complete construction projects. Int. J. Innov. Manag. Technol. 2011, 2, 477.

80. Zhou, H.; Wang, H.; Zeng, W. Smart construction site in mega construction projects: A case study on island tunneling project of Hong Kong-Zhuhai-Macao Bridge. Front. Eng. Manag. 2018, 5, 78-87. [CrossRef]

81. Abotaleb, I.S.; El-adaway, I.H. Managing construction projects through dynamic modeling: Reviewing the existing body of knowledge and deriving future research directions. J. Manag. Eng. 2018, 34, 4018033. [CrossRef]

82. Khan, K.I.A.; Flanagan, R.; Lu, S.-L. Managing information complexity using system dynamics on construction projects. Constr. Manag. Econ. 2016, 34, 192-204. [CrossRef]

83. Teo, M.M.; Loosemore, M. Community-based protest against construction projects: A case study of movement continuity. Constr. Manag. Econ. 2011, 29, 131-144. [CrossRef]

84. Teo, M.M.M.; Loosemore, M. Community-based protest against construction projects: The social determinants of protest movement continuity. Int. J. Manag. Proj. Bus. 2010, 3, 216-235. [CrossRef]

85. Ali, A.S.; Rahmat, I. The performance measurement of construction projects managed by ISO-certified contractors in Malaysia. J. Retail. Leis. Prop. 2010, 9, 25-35. [CrossRef]

86. Nguyen, L.D.; Ogunlana, S.O. A study on project success factors in large construction projects in Vietnam. Eng. Constr. Archit. Manag. 2004, 11, 404-413. [CrossRef]

87. Shelbourn, M.; Bouchlaghem, N.M.; Anumba, C.; Carrillo, P. Planning and implementation of effective collaboration in construction projects. Constr. Innov. 2007, 7, 357-377. [CrossRef]

88. Love, P.E.D.; Edwards, D.J. Determinants of rework in building construction projects. Eng. Constr. Archit. Manag. 2004, 11, 259-274. [CrossRef]

89. Frank, B. Artificial intelligence-enabled environmental sustainability of products: Marketing benefits and their variation by consumer, location, and product types. J. Clean. Prod. 2021, 285, 125242. [CrossRef]

90. Bienvenido-Huertas, D.; Farinha, F.; Oliveira, M.J.; Silva, E.M.J.; Lança, R. Comparison of artificial intelligence algorithms to estimate sustainability indicators. Sustain. Cities Soc. 2020, 63, 102430. [CrossRef] 
91. Gummesson, E. Qualitative research in marketing: Road-map for a wilderness of complexityand unpredictability. Eur. J. Mark. 2005, 39, 309-327. [CrossRef]

92. Esposito, E. The structures of uncertainty: Performativity and unpredictability in economic operations. Econ. Soc. 2013, 42, 102-129. [CrossRef]

93. You, J.; Chen, Y.; Wang, W.; Shi, C. Uncertainty, opportunistic behavior, and governance in construction projects: The efficacy of contracts. Int. J. Proj. Manag. 2018, 36, 795-807. [CrossRef]

94. Abdi, M.; Aulakh, P.S. Locus of uncertainty and the relationship between contractual and relational governance in cross-border interfirm relationships. J. Manag. 2017, 43, 771-803. [CrossRef]

95. Meardi, G.; Martin, A.; Riera, M.L. Constructing uncertainty: Unions and migrant labour in construction in Spain and the UK. J. Ind. Relat. 2012, 54, 5-21. [CrossRef]

96. Gosling, J.; Naim, M.; Towill, D. Identifying and categorizing the sources of uncertainty in construction supply chains. J. Constr. Eng. Manag. 2013, 139, 102-110. [CrossRef]

97. Arashpour, M.; Wakefield, R.; Lee, E.W.M.; Chan, R.; Hosseini, M.R. Analysis of interacting uncertainties in on-site and off-site activities: Implications for hybrid construction. Int. J. Proj. Manag. 2016, 34, 1393-1402. [CrossRef]

98. Cheung, S.O.; Wong, P.S.P.; Wu, A.W.Y. Towards an organizational culture framework in construction. Int. J. Proj. Manag. 2011, 29, 33-44. [CrossRef]

99. Adenfelt, M.; Lagerström, K. Enabling knowledge creation and sharing in transnational projects. Int. J. Proj. Manag. 2006, 24, 191-198. [CrossRef]

100. Ankrah, N.A.; Langford, D.A. Architects and contractors: A comparative study of organizational cultures. Constr. Manag. Econ. 2005, 23, 595-607. [CrossRef]

101. Cheung, S.-O. Critical factors affecting the use of alternative dispute resolution processes in construction. Int. J. Proj. Manag. 1999, 17, 189-194. [CrossRef]

102. Van Marrewijk, A. Managing project culture: The case of Environ Megaproject. Int. J. Proj. Manag. 2007, 25, 290-299. [CrossRef]

103. Ivanov, D.; Dolgui, A.; Sokolov, B.; Werner, F.; Ivanova, M. A dynamic model and an algorithm for short-term supply chain scheduling in the smart factory industry 4.0. Int. J. Prod. Res. 2016, 54, 386-402. [CrossRef]

104. Arciszewski, T.; De Jong, K.A. Evolutionary computation in civil engineering: Research frontiers. In Civil and Structural Engineering Computing: 2001; Saxe-Coburg Publications: Stirling, UK, 2001; pp. 161-184.

105. Lu, P.; Chen, S.; Zheng, Y. Artificial intelligence in civil engineering. Math. Probl. Eng. 2012, 2012, 145974. [CrossRef]

106. Chou, J.; Pham, A. Smart artificial firefly colony algorithm-based support vector regression for enhanced forecasting in civil engineering. Comput. Civ. Infrastruct. Eng. 2015, 30, 715-732. [CrossRef]

107. Adam, B.; Smith, I.F.C. Active tensegrity: A control framework for an adaptive civil-engineering structure. Comput. Struct. 2008, 86, 2215-2223. [CrossRef]

108. Adam, B.; Smith, I.F. Reinforcement learning for structural control. J. Comput. Civ. Eng. 2008, 22, 133-139. [CrossRef]

109. Manzoor, B.; Othman, I.; Pomares, J.C. Digital Technologies in the Architecture, Engineering and Construction (AEC) Industry-A Bibliometric-Qualitative Literature Review of Research Activities. Int. J. Environ. Res. Public Health 2021, 18, 6135. [CrossRef] [PubMed]

110. Shaheen, A.A.; Fayek, A.R.; AbouRizk, S.M. Methodology for integrating fuzzy expert systems and discrete event simulation in construction engineering. Can. J. Civ. Eng. 2009, 36, 1478-1490. [CrossRef]

111. Forcael, E.; Glagola, C.R.; González, V. Incorporation of computer simulations into teaching linear scheduling techniques. J. Prof. Issues Eng. Educ. Pract. 2012, 138, 21-30. [CrossRef]

112. Senouci, A.; Al-Derham, H.R. Genetic algorithm-based multi-objective model for scheduling of linear construction projects. Adv. Eng. Softw. 2008, 39, 1023-1028. [CrossRef]

113. Zavadskas, E.K.; Antucheviciene, J.; Vilutiene, T.; Adeli, H. Sustainable decision-making in civil engineering, construction and building technology. Sustainability 2018, 10, 14. [CrossRef]

114. Correia, A.G.; Cortez, P.; Tinoco, J.; Marques, R. Artificial intelligence applications in transportation geotechnics. Geotech. Geol. Eng. 2013, 31, 861-879. [CrossRef]

115. Cai, S.; Ma, Z.; Skibniewski, M.J.; Bao, S. Construction automation and robotics for high-rise buildings over the past decades: A comprehensive review. Adv. Eng. Inform. 2019, 42, 100989. [CrossRef]

116. Wakisaka, T.; Furuya, N.; Inoue, Y.; Shiokawa, T. Automated construction system for high-rise reinforced concrete buildings. Autom. Constr. 2000, 9, 229-250. [CrossRef]

117. Chu, B.; Jung, K.; Lim, M.-T.; Hong, D. Robot-based construction automation: An application to steel beam assembly (Part I). Autom. Constr. 2013, 32, 46-61. [CrossRef]

118. Jung, K.; Chu, B.; Park, S.; Hong, D. An implementation of a teleoperation system for robotic beam assembly in construction. Int J. Precis. Eng. Manuf. 2013, 14, 351-358. [CrossRef]

119. Hoc, J.-M. From human-machine interaction to human-machine cooperation. Ergonomics 2000, 43, 833-843. [CrossRef] [PubMed]

120. Läubli, S.; Castilho, S.; Neubig, G.; Sennrich, R.; Shen, Q.; Toral, A. A set of recommendations for assessing human-machine parity in language translation. J. Artif. Intell. Res. 2020, 67, 653-672. [CrossRef]

121. Pacaux-Lemoine, M.-P.; Trentesaux, D.; Rey, G.Z.; Millot, P. Designing intelligent manufacturing systems through Human-Machine Cooperation principles: A human-centered approach. Comput. Ind. Eng. 2017, 111, 581-595. [CrossRef] 
122. Wang, J.; Li, S.; Xiong, G.; Cang, D. Application of digital technologies about water network in steel industry. Resour. Conserv. Recycl. 2011, 55, 755-759. [CrossRef]

123. Berkhout, F.; Hertin, J. De-materialising and re-materialising: Digital technologies and the environment. Futures 2004, 36, 903-920. [CrossRef]

124. Mistry, D. Comparison of digital water marking methods. Int. J. Comput. Sci. Eng. 2010, 2, 2905-2909.

125. Bressanelli, G.; Adrodegari, F.; Perona, M.; Saccani, N. Exploring how usage-focused business models enable circular economy through digital technologies. Sustainability 2018, 10, 639. [CrossRef]

126. Merchant, G. Mobile practices in everyday life: Popular digital technologies and schooling revisited. Br. J. Educ. Technol. 2012, 43, 770-782. [CrossRef]

127. Lember, V. The Increasing Role of Digital Technologies. In Co-Production and Co-Creation; Taylor \& Francis: Abingdon, UK, 2018; p. 115.

128. Aleksandrova, E.; Vinogradova, V.; Tokunova, G. Integration of digital technologies in the field of construction in the Russian Federation. Eng. Manag. Prod. Serv. 2019, 11, 38-47. [CrossRef]

129. Chassignol, M.; Khoroshavin, A.; Klimova, A.; Bilyatdinova, A. Artificial Intelligence trends in education: A narrative overview. Procedia Comput. Sci. 2018, 136, 16-24. [CrossRef]

130. Lutz, C. Digital inequalities in the age of artificial intelligence and big data. Hum. Behav. Emerg. Technol. 2019, 1, 141-148. [CrossRef]

131. Kolbjørnsrud, V.; Amico, R.; Thomas, R.J. How artificial intelligence will redefine management. Harv. Bus. Rev. 2016, 2, 1-6.

132. Borges, A.F.S.; Laurindo, F.J.B.; Spínola, M.M.; Gonçalves, R.F.; Mattos, C.A. The strategic use of artificial intelligence in the digital era: Systematic literature review and future research directions. Int. J. Inf. Manag. 2020, 57, 102225. [CrossRef]

133. Al-Emran, M.; Mezhuyev, V.; Kamaludin, A.; Shaalan, K. The impact of knowledge management processes on information systems: A systematic review. Int. J. Inf. Manag. 2018, 43, 173-187. [CrossRef]

134. Bertone, E.; Burford, M.A.; Hamilton, D.P. Fluorescence probes for real-time remote cyanobacteria monitoring: A review of challenges and opportunities. Water Res. 2018, 141, 152-162. [CrossRef]

135. Hosseinzadeh-Bandbafha, H.; Nabavi-Pelesaraei, A.; Shamshirband, S. Investigations of energy consumption and greenhouse gas emissions of fattening farms using artificial intelligence methods. Environ. Prog. Sustain. Energy 2017, 36, 1546-1559. [CrossRef]

136. Bannerjee, G.; Sarkar, U.; Das, S.; Ghosh, I. Artificial intelligence in agriculture: A literature survey. Int. J. Sci. Res. Comput. Sci. Appl. Manag. Stud. 2018, 7, 1-6.

137. Bolandnazar, E.; Rohani, A.; Taki, M. Energy consumption forecasting in agriculture by artificial intelligence and mathematical models. Energy Sources Part A Recover. Util. Environ. Eff. 2020, 42, 1618-1632. [CrossRef]

138. Soofastaei, A. The application of artificial intelligence to reduce greenhouse gas emissions in the mining industry. In Green Technologies to Improve the Environment on Earth; IntechOpen: London, UK, 2018.

139. Magazzino, C.; Mele, M.; Schneider, N. The relationship between municipal solid waste and greenhouse gas emissions: Evidence from Switzerland. Waste Manag. 2020, 113, 508-520. [CrossRef]

140. Das, S.; Dey, A.; Pal, A.; Roy, N. Applications of artificial intelligence in machine learning: Review and prospect. Int. J. Comput. Appl. 2015, 115, 31-41. [CrossRef]

141. Talaviya, T.; Shah, D.; Patel, N.; Yagnik, H.; Shah, M. Implementation of artificial intelligence in agriculture for optimisation of irrigation and application of pesticides and herbicides. Artif. Intell. Agric. 2020, 4, 58-73.

142. Shahin, M.A. State-of-the-art review of some artificial intelligence applications in pile foundations. Geosci. Front. 2016, 7, 33-44. [CrossRef]

143. Shahin, M.A.; Jaksa, M.B.; Maier, H.R. Artificial neural network applications in geotechnical engineering. Aust. Geomech. 2001, 36, 49-62.

144. Manzoor, B.; Othman, I.; Gardezi, S.S.S.; Altan, H.; Abdalla, S.B. BIM-Based Research Framework for Sustainable Building Projects: A Strategy for Mitigating BIM Implementation Barriers. Appl. Sci. 2021, 11, 5397. [CrossRef]

145. AlArjani, A.; Modibbo, U.M.; Ali, I.; Sarkar, B. A new framework for the sustainable development goals of Saudi Arabia. J. King Saud Univ. 2021, 33, 101477. [CrossRef] 